\title{
Imprensa católica e identidade ultramontana no Brasil do século XIX: uma análise a partir do jornal $O$ Apóstolo
}

\author{
Catholic press and ultramontane identity in 19th century Brazil: \\ an analysis from the newspaper $O$ Apóstolo
}

Ana Rosa Cloclet da Silva*

\begin{abstract}
Resumo
O presente artigo analisa a experiência brasileira da secularização, observando o modo como, nas páginas da imprensa católica publicada na segunda metade do século XIX, o religioso e o secular se articularam de diferentes maneiras e se modelaram reciprocamente. Como argumento central, sustenta que a difusão das formas impressas, considerada uma das principais condições históricas associadas ao advento da modernidade ocidental, foi também responsável, no contexto analisado, pela veiculação dos referenciais associados ao catolicismo romanizado e a uma Igreja independente do regalismo imperial. Na sua defesa, clérigos e leigos de tendência ultramontana fizeram uso de diversos atores e instrumentos, dentre os quais a imprensa periódica. Desse modo, partindo do pressuposto teórico de que as identidades são portadoras de uma dimensão relacional e política, no âmbito da qual os conflitos sociais se traduzem em disputas discursivas, o artigo elege como fonte privilegiada o periódico $O$ Apóstolo, semanário católico editado no Rio de Janeiro entre 1866 e 1891 e um dos principais porta-vozes dos ideais e projetos ultramontanos. Mediante a análise de seus conteúdos discursivos, espera-se identificar alguns dos seus principais sentidos de alteridade -associados aos supostos "erros da modernidade" -, bem como uma identificação positiva atrelada às diretrizes emanadas da Santa Sé.
\end{abstract}

Palavras-chave: Ultramontanismo. Secularização. Identidades. Imprensa católica. O Apóstolo.

\begin{abstract}
This article analyzes the Brazilian experience of secularization, observing how, in the pages of the Catholic press published in the second half of the 19th century, the religious and the secular articulated in different ways and modeled each other. As a central argument, it maintains that the diffusion of printed forms, considered one of the main historical conditions associated with the advent of Western modernity, was also responsible, in this context, for the dissemination of references associated with Romanized Catholicism and a Church independent of imperial regalism. In their defense, clergy and laic with an ultramontane tendency used various actors and instruments, including the periodical press. Thus, based on the theoretical assumption that identities carry a relational and political dimension, in which social conflicts are translated into discursive disputes, the article select as a privileged source the journal $O$ Apóstolo, a Catholic weekly published in Rio de Janeiro between 1866 and 1891 and one of the main spokespersons for ultramontans ideals and projects. Through the analysis of its discursive contents, it is expected to identify some of its main meanings of otherness - associated with the supposed "errors of modernity" - as well as a positive identification linked to the guidelines emanating from the Holy See.
\end{abstract}

Keywords: Ultramontanism. Secularization. Identities. Catholic press. The Apostle.

Artigo submetido em 16 de fevereiro de 2020 e aprovado em 18 de agosto de 2020.

*Doutora em História pela Unicamp. Professora da PUC-Campinas. País de origem: Brasil. E-mail: anacloclet@gmail.com 


\section{Introdução}

Nas últimas décadas, a evidência assumida pelo fenômeno religioso nas sociedades ocidentais constitui um grande desafio para as Ciências Humanas. Inspirando um debate interdisciplinar e ainda não resolvido, tal cenário tem levado estudiosos do tema a problematizarem a pertinência das teorias clássicas da secularização, verdadeira moldura teórica sob cuja lente as relações entre religião e modernidade foram tradicionalmente pensadas (SILVA; DI STEFANO, 2017).

Especificamente, questiona-se o viés normativo assumido pelo uso tradicional da secularização como categoria analítica supostamente capaz de abarcar um processo histórico comum às sociedades ocidentais, marcado pela diferenciação das esferas sociais em relação à religião, pela emergência de uma visão de mundo racional e científica, distante da visão religiosa, assim como pela mundanização, referida tanto à simultânea perda de espaço do transcendente no mundo social, quanto ao envolvimento das instituições religiosas com questões cada vez mais mundanas e menos espirituais (RANQUETAT, 2016, p. 17). Na crítica do sociólogo José Casanova, deriva daqui uma auto-definição da modernidade "inevitavelmente tautológica, na medida em que a diferenciação secular é precisamente o que define uma sociedade como "moderna"' (CASANOVA, 2006, p. 10).

Inspirado na experiência das sociedades europeias ocidentais, tal paradigma tem se revelado insuficiente e mesmo inadequado para abarcar outros processos históricos de construção da modernidade, onde a emergência de uma esfera pública não, necessariamente, implicou a perda das funções moralizadora e integradora da religião, com seu deslocamento para a esfera da autonomia individual (HAUPT, 2008). Conforme nos mostra a antropologia do secularismo, de Talal Asad (2003), por exemplo, os processos de secularização e laicidade nunca se caracterizam pelo aparecimento de Estados neutros em matéria religiosa e de arenas públicas "desnudas", o que implica assumir que uma história das sociedades modernas deve 
considerar que a religião surgiu de forma paralela e em relação dialética com a formação do "secular".

Especificamente, torna-se assente que, do ponto de vista de suas manifestações concretas, a secularização traduziu um processo marcado pela concorrência entre diferentes propostas de modernidade, ${ }^{1}$ de cujos embates produziram-se combinações complexas entre a perda do domínio dos grandes sistemas religiosos e as reconfigurações da religião por sociedades que continuaram reivindicando-a como condição para pensarem-se a si mesmas como politicamente autônomas (HERVIEU-LÉGER, 2004, p. 37). Neste embate, a Igreja católica passou por sucessivos movimentos de reforma, mediante os quais o "paradigma tridentino" - que teria marcado a história da instituição desde a crise do Medievo - fora atualizado (PRODI, 2010, p. 19), abrindo caminho para que a própria Igreja se revelasse um dos atores principais da "secularização" (DI STEFANO, 2008)

Tal enfoque tem se revelado profícuo para se pensar a experiência brasileira, situada ao lado daquelas outras experiências socioculturais, associadas ao advento das sociedades modernas e seculares. Indagando acerca das condições históricas sob as quais se reconfiguraram as articulações entre os sistemas religiosos e as demais esferas da realidade, é possível identificar uma tendência comum, que vincula o Brasil aos demais contextos latino-americanos. Referimo-nos ao fato de que, nestes países, o conjunto de transformações sociais e culturais que acompanharam "a dissolução do regime de cristandade ibérico, que teve lugar a partir - e em parte como resultado - da crise das metrópoles coloniais", ensejaram diferentes processos de "modernidade religiosa", conceito que define as experiências concretas de secularização aí observadas, as quais foram marcadas por "transformações nas formas como os individuos se relacionam com o sagrado e com as instituições que o administram; nas funções e na organização dessas

\footnotetext{
${ }^{1}$ Neste sentido, desfaz-se tanto a identificação entre "modernidade" e "ocidentalização" - emergindo outras referências e padrões não ocidentais de sociedades modernas - quanto à compreensão dessas "modernidades" como "estáticas", uma vez que "se encontram antes em constante mutação". (EISENSTADT, 2001, p. 139-163).
} 
instituições e nos vínculos que estabelecem com um poder civil cujos fundamentos já não remetem à religião herdada” (DI STEFANO, 2018, p. 135, tradução nossa).

Dentre as estratégias assumidas para manter-se influente, "definindo espaços e margens de ação" e impondo-se "determinadas modalidades de presença nas vidas dos indivíduos e das comunidades" (DI STEFANO, 2018, p. 135), a Igreja católica e seus agentes apropriaram-se da imprensa periódica, ator fundamental dos processos de "modernidade política" (XAVIER-GUERRA, 2009) em curso ao longo do século XIX, mas que, também, funcionou como um dos principais portavozes do pensamento católico, inclusive de sua vertente mais antiliberal: o ultramontanismo.

Como consequência, foram vários os jornais católicos ultramontanos que surgiram no período em foco, demonstrando que seus colaboradores estavam "cientes da enorme importância do bom uso dos meios de difusão das ideias, bem como da construção e do fortalecimento de uma opinião pública a eles favorável" (NEVES, 2013). Assim, através deste veículo, os representantes do ultramontanismo no Brasil mobilizaram-se num verdadeiro esforço de sobrevivência enquanto grupo religioso institucionalizado, pulverizando as emanações vindas de Roma com a finalidade de modelar hábitos $\mathrm{e}$ comportamentos sociais, firmar a obediência aos sacramentos, disciplinar aspectos da religiosidade popular, bem como cuidar da própria reforma do clero. Ao mesmo tempo, esculpiram uma identidade ultramontana, dimensão menos tangível embora não menos importante - do processo de secularização da sociedade brasileira, a qual foi tecida mais pela negatividade - a recusa aos supostos "erros" da modernidade occidental - que pelos referenciais de positividade, capazes de conferir coesão a um projeto encampado em nível nacional.

Nas reflexões que seguem, portanto, procuraremos situar os referenciais e a dinâmica da construção identitária deste catolicismo marcadamente romanizado e ultramontano, que, sobretudo a partir do Concílio Vaticano I, em 1869, assumiria o modelo de Sociedade Perfeita emanado da Santa Sé. Partindo do pressuposto 
teórico de que as identidades são portadoras de uma dimensão relacional e política, no âmbito da qual as disputas sociais ocupam lugar central na produção das ideias de diferença e dos sentidos de pertença por indivíduos e grupos, a pesquisa elege como fonte privilegiada o periódico $O$ Apóstolo, semanário ultramontano editado no Rio de Janeiro a partir de 7 de dezembro de 1866, o qual circulou por 35 anos, adentrando o período republicano. ${ }^{2}$

Nas suas páginas, leigos e clérigos travaram uma verdadeira batalha discursiva, mobilizando conceitos e referenciais que, se por um lado indicavam as mudanças sociais e políticas em curso, por outro, permitiam tomar consciência da necessidade de reconfiguração do próprio catolicismo, derivando uma experiência concreta de "modernidade religiosa".

\section{A imprensa católica como braço do ultramonanistmo}

No Brasil, os nexos entre política e religião definiram-se historicamente pelo regime do padroado, vigente "em Portugal e nas suas colônias desde os tempos coloniais, mediante o qual estabeleceu-se o forte predomínio do Estado sobre a Igreja" (SANTIROCCHI, 2015, p. 24), inviabilizando a independência institucional entre ambos. Sob este regime, configurou-se a hegemonia da vertente galicana do catolicismo brasileiro, até por volta de 1837, reconfigurando o padroado régio em padroado imperial, cuja legitimidade passava a ser de natureza constitucional.

A tal modelo - que desde meados do século XVIII passou a ser pejorativamente chamado de regalismo3, contrapunham-se os defensores do primado pontifício, designados como "ultramontanos", cuja escola de pensamento era o "ultramontanismo", tributária da escolástica peripatética e do tomismo (ARAÚJO, 2014, p. 77-106). Embora o termo "ultramontanismo" remonte à

\footnotetext{
2 Esta faz parte do acervo da Hemeroteca Digital Brasileira, organizado pela Biblioteca Nacional, disponível em: http://memoria.bn.br/hdb/uf.aspx.

3 Termos que se consagram no contexto do reformismo pombalino, para significar um sistema pelo qual, supostamente, "as concessões recebidas pelos reis para a manutenção da fé foram, muitas vezes, ampliadas e modificadas arbitrariamente pelo Estado" (CASTRO, 2002).
} 
linguagem eclesiástica medieval,4 foi somente no século XIX que passou a significar o pensamento e a postura da Igreja Católica frente às transformações trazidas pela Revolução Francesa. Essa fase da Igreja foi descrita pela historiografia como conservadora, pois, em reação às novas tendências políticas, seus representantes buscaram reafirmar o escolasticismo, reestabelecer a Companhia de Jesus e apoiarse nas diretrizes do Concílio de Trento. (HAUCK, 1992)

No Brasil, a tradição galicana foi perpetuada após a independência graças à legitimidade política galgada pelo um grupo de clérigos representativos desta tendência, com destaque para o padre e estadista Diogo Antônio Feijó. Assim, fundida ao Estado, a Igreja Católica preservara seu monopólio na produção, gestão e veiculação do capital religioso junto à sociedade brasileira, o que era garantido pela Constituição de 1824, cujo Art. $5^{\circ}$. reconhecia a religião católica como a oficial e mantinha a Igreja subordinada ao Estado.

A longa vigência do padroado implicou que, embora atuantes em nível do Parlamento5 e das vias não institucionais ${ }^{6}$, os representantes do ultramontanismo permanecessem, durante toda a primeira metade do século XIX, pouco propositivos no que concerne à questão da "regeneração do clero e da Igreja brasileira", tendo antes reagido aos "projetos que visavam a modernizar a religião, segundo os ditames liberais". (SOUZA, 2010, p. 397).

Dessa forma, a viabilidade do modelo de Igreja proposto pelo clero ultramontano teria que aguardar as circunstâncias históricas delineadas, sobretudo, a partir de meados do século XIX. Foi neste contexto, marcado pelo

\footnotetext{
${ }^{4}$ Segundo Ítalo Domingos Santirocchi, "a palavra ultramontano deriva do latim, ultramontes, que significa "para além dos montes", isto é, dos Alpes." Na sua origem, denominava todos os Papas não italianos. Acrescenta, ainda, que no século XIII, o conceito passou a ser usado para "identificar os defensores da Igreja em qualquer conflito entre os poderes temporais e espirituais". (SANTIROCCHI, 2010, p. 24).

${ }^{5}$ Destacaram-se, neste sentido, D. Romualdo Antonio de Seixas - arcebispo da Bahia - e o bispo do Maranhão - Marcos Antônio de Sousa -, defensores do modelo "intransigente romano", que negava ser o direito do padroado inerente à soberania dos governos temporais, concebendo-o como mera concessão papal e defendendo os "direitos da Igreja" como instituição independente e, inclusive, hierarquicamente superior ao poder civil, sujeita apenas à Santa Sé.

${ }^{6}$ Destacam-se, aqui, dois dos principais representantes do clero ultramontano: os padres publicistas Luís Gonçalves dos Santos apelidado de "Padre Perereca" - e William Paul Tilbury, sacerdote inglês que emigrara para o Brasil e aqui mudara de nome para Guilherme Paulo Tilbury. Estes padres veicularam na imprensa da época ferrenhas críticas ao regalismo - alimentando um debate direto com o padre Diogo Feijó -, bem como ao protestantismo de missão ou conversão, como era o caso dos metodistas, primeiros protestantes a mandarem missionários ao Brasil. (SILVA; CARVALHO, 2017)
} 
surgimento de uma via de secularização apoiada no princípio liberal da liberdade religiosa e da neutralidade do Estado neste sentido, que os representantes do clero ultramontano, então favorecidos pela política imperial,7 mobilizaram-se contra toda e qualquer tendência associada ao liberalismo anticlerical, à maçonaria e ao pensamento filosófico científico, que eram contrários aos princípios da Igreja Romana. No campo das controvérsias, designaram como principais oponentes o antigo modelo regalista (ainda vigente, embora politicamente enfraquecido) e o protestantismo (concorrente mais direto no campo religioso cristão), ambos cumprindo o papel de "equivalente funcional da visibilidade" e da "legitimidade social" construída pelos ultramontanos. (MONTERO, 2012)

Contra estas tendências, houve a reabilitação da intolerância, coragem, caridade e espírito apologético pelos clérigos ultramontanos, nos marcos do movimento conhecido como a "romanização" da Igreja Católica: processo que tendeu a afirmar a autoridade de uma Igreja institucional e hierárquica, diretamente subordinada a Roma e cada vez mais dependente de padres estrangeiros pertencentes às congregações e ordens missionárias, enviados ao Brasil com a função de "controlar a doutrina, a fé, as instituições e a educação do clero e laicato". ${ }^{8}$

Do ponto de vista de sua orientação, tais reformas foram referenciadas em dois documentos emitidos pelo papa Pio IX, em dezembro de 1864: a Encíclica Quanta Cura - que deveria oferecer uma síntese dos erros relacionados à sociedade moderna e, especialmente, à questão da liberdade de consciência -, seguida pelo Syllabus - uma lista contendo tais erros, representando a resposta ortodoxa da Igreja católica à sociedade contemporânea.

\footnotetext{
${ }^{7}$ O motivo desta ascensão radica no próprio ambiente político e social do final do Período Regencial e do início do Segundo Império, sendo que o envolvimento do clero liberal regalista nos movimentos revolucionários das províncias e na política partidária provocou a reação do Estado e do episcopado nacional, levando o Governo a privilegiar os ultramontanos para ocuparem essas cadeiras. (SANTIROCCHI, 2011, p. 188)

${ }^{8}$ O termo "romanização" chegou ao Brasil a partir da tradução do livro prefaciado por Rui Barbosa, O Papa e o Concílio, de Döllinger, publicado no Brasil em 1877. Nesta, o teólogo liberal de Munique protestava contra o crescente absolutismo papal e o reavivamento da teologia escolástica, sendo marco das manifestações contrárias à definição do dogma da infalibilidade papal. (SANTIROCCHI, 2010).
} 
Definia-se, assim, o projeto de modernidade oficialmente encampado pela Igreja católica, de moldes tridentinos e apoiado no dogma da infalibilidade do poder papal e na defesa da autonomia institucional da Igreja frente ao poder temporal. No Brasil da segunda metade do século XIX, seria este o principal referencial coesivo de leigos e clérigos ultramontanos, inicialmente sustentado pelo episcopado nacional, mas que não tardaria a mobilizar diversos instrumentos e atores.

Neste cenário, a imprensa periódica, ao mesmo tempo que representou um importante ator na transformação dos espaços públicos e construção da modernidade política (ANDERSON, 1989), tornou-se, também, um dos principais porta-vozes dos ideais e projetos ultramontanos, sendo vários os jornais católicos que surgiram na segunda metade do século XIX e no início do período republicano.

Os estudos sobre a história da imprensa católica no país, embora em flagrante expansão, ainda se revelam essencialmente monográficos e focados em periódicos específicos, o que dificulta uma visão de conjunto, capaz de apreender as principais tendências e fases desses jornais, que tiveram sua "explosão" especialmente no período de 1870 a 1900 . Um levantamento destes jornais a partir do acervo da Hemeroteca Digital da Biblioteca Nacional9, nos permite concluir que, se até o período regencial a imprensa ultramontana era pouco sistemática e de caráter panfletário, ${ }^{10}$ já a partir de meados do século XIX, assume uma dimensão projetiva e combativa, acompanhando a ascensão e legitimidade galgada pelo modelo "intransigente romano".

O quadro abaixo nos permite uma visão do conjunto dos jornais católicos editados durante a segunda metade do século XIX, constantes da Hemeroteca Digital da BN. Tratam-se de jornais, revistas e almanaques de diferentes periodicidades (diário, semanal, quinzenal, mensal e circulação irregular),

\footnotetext{
${ }^{9}$ Disponível em: http://bndigital.bn.gov.br/sobre-a-bndigital/historico/

${ }^{10}$ Marco deste debate foi a polêmica suscitada pelo projeto de abolição do celibato, apresentado pelo padre Diogo Feijó na Câmara dos Deputados, em sessão de 1827, e veiculado nas páginas do jornal O Justiceiro, por ele editado entre 1834-35. Contra os "projetos casamenteiros" de Feijó, insurgiu a crítica ultramontana de Luis Gonçalves dos Santos (o "Padre Perereca"), que, aliado a outro padre inglês aqui radicado (William Tilbury), estendeu tal crítica ao próprio regalismo de matriz pombalina, simbolicamente associado ao protestantismo, cujos primeiros expoentes começavam a se fixar no Brasil, representados pelos metodistas. (SILVA; LOURENÇO, 2015).
} 
compondo um conjunto muito diversificado de publicações, geralmente de caráter noticioso, cuja sobrevida era garantida pela venda de espaço publicitário dentro da publicação e por assinantes da mesma. Uma triagem por este universo documental nos permitiu identificar, para o período de 1850 a 1899 um total de 2.962 publicações disponíveis, das quais 66 jornais foram identificados como católicos, de tendência ultramontana. Embora num primeiro momento possa parecer um número reduzido (representando apenas 2,25\% do total de periódicos do período), vale notar que, quando comparado aos jornais de outras denominações religiosas, ele é praticamente absoluto.

\begin{tabular}{|r|r|r|r|}
\hline & total & catolicos & $\%$ \\
\hline $1850-1859$ & 261 & 12 & 4,6 \\
\hline $1860-1869$ & 368 & 16 & 4,3 \\
\hline $1870-1879$ & 560 & 13 & 2,3 \\
\hline $1880-1889$ & 860 & 7 & 0,8 \\
\hline $1890-1899$ & 877 & 18 & 2,1 \\
\hline & 2926 & 66 & 2,3 \\
\hline
\end{tabular}

Fonte: Hemeroteca Digital da BN

Neste período, portanto, foram editados alguns dos mais importantes jornais católicos do período (RODRIGUES, 1981, p. 7-8), incluindo O Apóstolo, principal e mais longevo deles, que já na sua segunda edição, manifestava esta sua "razão de ser":

A liberdade de imprensa é uma consequência legítima e necessária da liberdade, que o criador dera ao pensamento. São bem conhecidas as dificuldades com que luta a imprensa religiosa em tempos que não afagam leituras dessa ordem, ou antes, parece dizê-lo com mais verdade, quando tudo parece conspirar para derrubar o edifício eterno da Igreja. Pois bem, ainda assim o nosso periódico achou apoio porque Deus abençoou as nossas intenções, que outras não foram [...] senão o interesse dessa religião que, apesar de perseguida, é único poder que há de salvar o mundo. (O Apóstolo, n. 2, 1/12/1866, p. 1).

Até 1870, a atuação destes jornais revela que a "autocompreensão central era de que a Igreja Católica no Brasil estava visceralmente ligada à Sé Romana, mas que caminharia ao lado do trono" (PINHEIRO, 2009, p. 9). Aliás, foi justamente 
este alinhamento dos ultramontanos com a monarquia constitucional que levou o Estado a preferi-los para as nomeações episcopais, aos padres alinhados com o liberalismo. Contudo, as relações e vínculos estabelecidos com o Estado Imperial mudariam a partir de 1870, quando, além do maior atrelamento às diretrizes de Roma, houve um enfraquecimento da concepção de vínculo entre o Trono e o Altar, em virtude da Questão Religiosa, em 1872,11 levando os ultramontanos brasileiros a desafiar a legislação nacional, que limitava a autoridade pontifícia sobre os assuntos religiosos e a autonomia da hierarquia eclesiástica nacional.

A este respeito, o Apóstolo manifestava-se abertamente contra a decisão do Trono e de membros da sociedade civil, nos seguintes termos:

Está pois erguido bem alto um muro de recíproca desconfiança e viva antipatia entre o sacerdócio católico e a maçonaria, entre o Episcopado e o Grande Oriente. O silêncio dos amigos da Igreja e da ordem pública nestas horríveis conjunturas é um crime contra Deus, uma suspeita de heresia contra a Igreja, uma alavanca de desordem contra a pátria que precisa de paz e concórdia para progredir na estrada da civilização e da prosperidade que lhe sorri no presente e muito mais no futuro". (O Apóstolo, n. 35, 1/09/1872).

A nosso ver, portanto, entre 1872 e $1890^{12}$ delineia-se uma fase crucial do afastamento entre Igreja e Estado no Brasil e, simultaneamente, de um maior alinhamento dos clérigos de tendência ultramontana às diretrizes da Santa Sé. Nas páginas do jornal $O$ Apóstolo, é possível identificar um esforço de identificação entre catolicismo e ultramontanismo, cujos referenciais passaremos a analisar. Embora não se possa inferir daí a construção de uma identidade ultramontana em nível nacional - nem, tampouco, em que medida o jornal analisado foi eficaz em moldar hábitos e comportamentos de seus leitores ${ }^{13}$-, cabe frisar que, em suas

\footnotetext{
${ }^{11}$ Como é sabido, esta consistiu na polêmica que repercutiu profundamente nas relações entre o Trono e o Altar, em virtude da condenação imposta ao padre José Luís de Almeida Martins pelo bispo D. Pedro Maria de Lacerda, em represália ao fato daquele ter discursado na comemoração da Lei do Ventre Livre, organizada pela loja Maçônica Grande Oriente do Lavradio, em homenagem ao Visconde do Rio Branco, grão-mestre maçom e Presidente do Conselho de Ministros do Império. Esta decisão foi apoiada pelos bispos do Pará - D. Macedo Costa - e da diocese de Pernambuco - D. Vital - que em cumprimento às decisões pontifícias que condenavam a maçonaria, "requereram que as irmandades retirassem do seu grêmio os membros que pertenciam a dita sociedade secreta". As confrarias que se recusaram a cumprir tal determinação apresentaram um "recurso à Coroa", que foi acatado, resultando ainda na condenação e prisão dos referidos bispos, anistiados em 1875. (SANTIROCCHI, 2015).

${ }^{12}$ Neste ano, o Decreto de 7 de janeiro, antecedendo o texto constitucional, "introduziu a liberdade religiosa e privou a Igreja Católica dos privilégios de que havia gozado até então como religião oficial do Estado", delineando uma nova fase das relações entre Igreja e Estado no Brasil. (RODRIGUES, 1978, p. 7).

${ }^{13}$ Neste sentido, o clássico argumento de Lustosa (1983) acerca do suposto empenho coeso do episcopado brasileiro na organização da imprensa católica vem sendo problematizado por interpretações recentes, preocupadas em "enfocar as disputas e tensões que existiram entre a Santa Sé e a hierarquia eclesiástica brasileira". O que redundaria não apenas na resistência a uma "articulação do
} 
páginas, identifica-se a estratégia de produzir, simultaneamente, "o pertencimento e a alteridade", por meio de uma específica forma de pensarem e imaginarem o lugar da religião no mundo moderno, "a partir do contexto e das relações sociais" nos quais seus redatores estavam envolvidos. ${ }^{14}$

No contexto aqui recortado, tal estratégia foi modelada a partir das contingências da sociedade brasileira e, em particular, das relações entre Estado imperial e Igreja católica. Contudo, numa perspectiva mais ampla, os referenciais em voga foram tributários de uma autocompreensão da Igreja que, simultaneamente, afirmava a perspectiva tridentina, sobretudo do ponto de vista dogmático, e buscava alinhar suas estratégias e propósitos ao processo de secularização das sociedades ocidentais. Neste sentido, a atuação dos ultramontanos através da imprensa esteve alinhada a uma "autocompreensão eclesial” que, segundo Ivan Manoel, designaria a ação da

Igreja na sua vertente institucional em um dado momento histórico, onde o Papa (entenda-se, a hierarquia eclesiástica) define um conceito de Igreja, estabelece suas tarefas e estratégias de ação e reordena sua política interna em função de seu projeto político e pastoral externo, e essa nova forma de autoentendimento permanecerá em vigência até ser substituída por outra, gerada nas suas próprias contradições internas e externas. (MANOEL, 2004, p. 10).

Neste sentido, é possível assumir que $O$ Apóstolo registra esta dinâmica de simultânea produção da identidade e das alteridades do ultramontanismo, traduzida na mobilização de um repertório prévio de vocábulos e referenciais, cujos conteúdos estiveram em disputa como parte das respostas possíveis dos agentes a um dos principais questionamentos coevos: o que indagava acerca do lugar da religião na sociedade brasileira.

Iniciemos, então, pela qualificação daquilo que o ultramontanismo identificava como os supostos "inimigos da Igreja católica", no conjuntura analisada.

episcopado para implantar as reformas institucionais", como no fracasso da "tentativa de fundar um jornal diário, que circulasse em todo o país e que fosse financiado por uma sociedade católica”. (MARIN, 2018, p. 202-203).

${ }^{14}$ Dinâmica comum aos processos de construção identitária, segundo Ennes e Marcon (2014, p. 287). 


\section{Nomeando as alteridades}

Fundado em 1866 e circulando até 1901, o jornal O Apóstolo inaugura uma fase mais ampla, informativa e combativa da imprensa católica, mobilizando seus discursos contra o galicanismo, o jansenismo, o regalismo, todos os tipos de liberalismo, protestantismo, maçonaria, deísmo, racionalismo, socialismo, casamento civil, liberdade irrestrita de pensamento e expressão, além de outras tendências associadas aos "erros' da modernidade em voga - referidas como as "cabeças de hidra da fábula" ( $O$ Apóstolo, n. 1, 7/01/1866) -, condenadas pelos "principais documentos pontifícios que circulavam na época em que $O$ Apóstolo começou a ser editado. 15

Neste sentido, os redatores do jornal deixavam claros os sentidos de alteridade em relação aos quais deveriam construir sua identidade e lutar pela autonomia institucional da Igreja. A “imprensa ímpia” - expressão que designava os jornais leigos que não professavam a mesma causa, assim como a imprensa protestante, cuja difusão no Brasil se dá a partir da década $1860^{16}$ - era um dos seus principais alvos. Na sua edição 29, de 22 de julho de 1866, o jornal informava sobre o breve ao Civiltá Cattolica, enviado pelo Papa Pio IX, expressando esta concepção acerca do significado paradoxal assumido pela imprensa, reconhecida como principal instrumento mobilizado pelos inimigos do catolicismo, mas, ao mesmo tempo, como indispensável arma na modelagem da realidade social e simbólica segundo os desígnios ultramontanos. Segundo o jornal,

a missão do século XIX exige em primeiro lugar que sejam dissipados os erros e que às inteligências transviadas faça-se patente a verdade. Ninguém pode pois desconhecer que a imprensa periódica e não periódica é nas mão dos inimigos da Igreja, a arma mais mortífera para combater qualquer espécie de bem e seduzir os espírito mais retos e sinceros. Para remediar a tão grande mal era necessário que homens cheios de coragem e talento, que padres zelosos, principalmente, empreendessem a obra mais salutar que é preciso tentar - a de oporem-se aos ataques tão perigosos da imprensa ímpia com as armas ministradas pela imprensa católica. ( $O$ Apóstolo, n. 29, 22/07/1866).

\footnotetext{
${ }^{15}$ Antecedendo o Concílio do Vatricano I, tratam-se estas ideias que definiram a ortodoxia católica nortearam os termos assinados pelos papas Gregório XVI (1831-1845), Pio IX (1846-1878), Leão XIII (1878-1903) e Pio XI (1922-1939)". (Pinheiro, 2009)

${ }^{16}$ Destaca-se nas páginas do Apóstolo o embate direto com o principal periódico protestante da época: a Imprensa Evangélica, que começou a circular no ano de 1864.
} 
A imprensa católica aparecia, assim, como imbuída da "missão sublime e indeclinável de guiar os povos pela senda do dever". Conforme registrado já na primeira edição do jornal: "Esses órgãos são os pastores, e enfim todo o Sacerdócio a quem o Divino Mestre nomeou a luz do mundo, o sol da terra. (O Apóstolo, n. 1, 7/01/1866)

Num sentido mais geral, a crítica ultramontana dirigia-se ao "racionalismo do século". Referindo-se ao amontoado de "invenções sobre invenções", ancoradas na "razão humana", argumentava na mesma edição:

Eis porque a religião católica parece aos espíritos do século um anacronismo retrógrado. Ela é o amor e a unidade, enquanto que o racionalismo, que traduz toda a licença intelectual, moral e social, quebra todos os laços do dever, desde a família até a Divindade. Liberdade sem freio, sem critério, sem fim possível; tomando como a hidra da fábula diversas cabeças, mas sempre o mesmo erro fatal com diversos nomes: na ordem pública - anarquia; na política - republicanismo; no domínio das ideias - filosofismo; na religião protestantismo”. (O Apóstolo, n. 1, 7/01/1866).

Os sentidos de alteridade acima mencionados serão detalhados em diversos números do Apóstolo, cujos artigos fazem antever "um sinistro futuro" ( $O$ Apóstolo, n. 34, 26/o8/1866), impondo ao catolicismo retomar sua sagrada missão de combater tudo que pudesse ser identificado como "heresia"17. É assim que, na sua edição de 26 de junho de 1870, o editorial "O Apóstolo", referindo-se à suposta deterioração das ordens regulares, em função das vendas dos seus bens pelo Estado, alertava:

Preparem-se os católicos brasileiros para assistirem a uma nova, perniciosa e horrível ordem de coisas, que as ideias volterianas de nossos legisladores e do governo vão estabelecer contra a Igreja, da qual tão hipocritamente se confessam filhos obedientes (...). Hoje as ordens religiosas. Amanhã o Sacrossanto Matrimônio. E assim por diante serão atacados todos os princípios fundamentais da Igreja, até que novas conveniências, a que costumam dar o nome falso de necessidades do Estado, venham a exigir a extinção da Igreja Católica no Brasil. (O Apóstolo, n. 27, 26/o6/1870).

\footnotetext{
${ }^{17}$ Neste sentido, o jornal expressava a clássica oposição entre ortodoxia e heresia, que funda a dinâmica historicamente observada por Pierre Bourdieu, mediante a qual, toda "prática ou crença dominada está fadada a aparecer como profanadora na medida em que, por sua própria existência e na ausência de qualquer intenção de profanação, constitui uma contestação objetiva do monopólio da gestão do sagrado e, portanto, da legitimidade dos detentores deste monopólio". (BOURDIEU, 2013, p. 65).
} 
Neste ponto, vale salientar que o campo religioso delineado pelas disputas em torno dos referenciais em voga, além de denunciar a complexa interferência entre religião e política, esteve marcado por uma dupla tensão. De um lado, combatia todas aquelas tendências associadas às veleidades modernas - como as correntes liberais, positivistas, protestantes, maçônicas, entre outras -, que circulavam a época. De outro, é preciso considerar que o catolicismo também não configurava um corpo homogêneo, inexistindo uma postura monolítica da Igreja e de seus representantes, tanto em termos dos assuntos temporais, quanto dos de natureza religiosa.

Por isso, em suas críticas, os redatores do jornal associavam os males do presente à tradicional relação entre Igreja e Estado, sustentada pelo modelo regalista, cujos representantes eram apontados como "adversários da Igreja" ( $O$ Apóstolo, n. 42, 10/04/1874). Na sua edição de 10 de fevereiro de 1874, O Apóstolo posicionava-se a tal respeito, defendendo os "Direitos da Igreja" separados do poder civil, "consequência lógica do dogma evangélico da distinção dos dois poderes e da independência do poder eclesiástico, não podendo subsistir evidentemente esta distinção e independência, se as causas eclesiásticas passassem a ser tratadas no foro civil”. Assim, defender o contrário, seria "apostatar da fé, pois a doutrina regalista contrária está condenada, e é realmente uma heresia”. ( $O$ Apóstolo, n. 21, 10/02/1874)

O jornal descrevia as circunstâncias atuais da Igreja católica no Brasil, como totalmente privada de "liberdade, não obstante saber-se que a liberdade é o maior bem que a ela se pode fazer [...]". Situação atribuída "a essa legislação inspirada pelo ódio, que o regalismo aqui plantou e continuamos a cultivar, que embaraça, entorpece e nulifica a ação da Igreja”. (O Apóstolo, n. 34, 22/08/1869).

Retrógrado, portanto, não era o ultramontanismo, mas o modelo regalista. Daí a importância atribuída à independência do episcopado, principalmente após os episódios que marcaram a Questão Religiosa, sobre a qual as edições do ano de 1874 posicionaram-se detalhadamente: 
Os Bispos do Brasil, pois recebem do tesouro magras côngruas, devem obediência ao governo (...). Pois Bem! Os Bispos do Brasil ganhariam trocando as mesquinhas côngruas pela extrema pobreza, contanto que os deixassem governar seus rebanhos em paz. Como as abelhas fabricam o mel se não as perturbam, os Bispos firmariam as boas doutrinas da Igreja, se o governo que mal pode dar conta do ensino profano, se não metesse a dar regras no ensino espiritual. (O Apóstolo, n. 42, 1/04/1874).

Além de viver uma etapa de tensão e conflito com o Estado - do qual era dependente em termos jurídicos e econômicos - a Igreja Católica sofria com as ações de propaganda de liberais e maçons, que disputavam os mesmos espaços que os ultramontanos - o Parlamento, a imprensa, os estabelecimentos de ensino superior e as próprias instituições religiosas - e concorriam pelos mesmos atores e bens simbólicos. Cabia, portanto, qualificar este sentido mais geral das alteridades e estabelecer, no plano discursivo, as diferenças que os opunham à identidade ultramontana.

Assim, a propósito do artigo intitulado "O Liberalismo", publicado em número anterior, argumentava-se:

Há liberalismo ideal ou teórico, e liberalismo real ou histórico. O liberalismo ideal ou teórico é o que cada qual quer que seja. É o liberalismo dos que vivem no mundo das ilusões e, portanto, dele não falamos. O liberalismo real, o único liberalismo que se conhece na história, consiste no propósito de Dar a César o que é de Deus. Não é outra coisa o liberalismo. Consulte-se a história, e ver-se-á como esse sistema, por mais que se chame político, tende sempre para ir alargando a esfera civil à[s] expensas da esfera religiosa. $\mathrm{O}$ liberalismo, que no fundo é só o naturalismo, procura conseguir que o homem se esqueça de Deus cada vez mais. (O Apóstolo, n. 83, 25/04/1875).

$\mathrm{Na}$ interpretação do jornal, estes princípios encontravam adeptos na sociedade brasileira - uma vez que a "França revolucionária foi e é desgraçadamente a escola dos nossos políticos, antes e depois da independência" (O Apóstolo, n. 29, 10/071870) -, sendo a maçonaria a presença mais execrável, pois, argumentava-se: "disfarçando-se debaixo de certas aparências de piedade [...] trabalha ao mesmo tempo [para] solapar com mão sacrílega e misteriosa os alicerces da autoridade eclesiástica" ( $O$ Apóstolo, n. 10, 09/03/1873). Nas páginas do jornal, a maçonaria era vista mesmo como "a Revolução em ação", movendo 
tanto a Revolução de 1789, como os princípios socialistas em voga no mundo ocidental. Conforme publicado,

a maçonaria não tem feito só revoluções, ela é a Revolução mesma. Ela é a desorganização social reduzida a sistema; é o socialismo! É a negação da autoridade" (...) O que foi a grande Revolução, a Revolução por excelência, começada em 1789, senão a maçonaria em ação? (...). É impossível negar que a soberania do homem, a liberdade e a fraternidade maçônicas foram o princípio gerador da grande revolução, que abateu juntamente o trono e o altar: eis o que é a maçonaria. (O Apóstolo, n. 28, 13/07/1873).

No Brasil, argumentava, a maçonaria encontraria apoio junto aos regalistas, ambas as tendências valendo-se da "pleníssima liberdade de imprensa para mentir, caluniar, blasfemar e desmoralizar”. Apontavam, aqui, a contradição dos próprios regalistas que, embora combatessem "qualquer associação religiosa que não queira em tudo e por tudo submeter-se à direção do governo”, privilegiava e isentava a maçonaria de toda sindicância, muito embora esta constituísse "verdadeiramente um Estado no Estado”. (O Apóstolo, n. 27, 26/06/1870)

Por fim, cabe mencionar os ataques do jornal àquele que, na conjuntura assinalada, constituía seu mais direto concorrente pelo capital simbólico: o protestantismo. Neste assunto, a crítica ultramontana dirigia-se a um dos efeitos mais marcantes da secularização: a defesa da liberdade religiosa ${ }^{18}$. É contra esta crescente tendência que os editores do Apóstolo mobilizavam-se, denunciando os propósitos daqueles “reformadores protestantes”, membros do Parlamento:

Não: não é o amor da pátria que inspira nos preparadores do futuro do Brasil a liberdade religiosa (...). Não fazemos aos seus membros a injúria de supor que eles não alcançam as consequências funestas de tão perigosas doutrinas; homens de inteligência, ou eles têm pouco meditado assunto tão grave, ou o bem do país é apenas um pretexto habilmente aproveitado para a importação do protestantismo com todas as fraquezas legais, como o meio mais cômodo desse viver livre e desabusado das consciências que nada mais conhecem e temem do que as coisas deste mundo”. (O Apóstolo, n.14, 8/4/1866).

Em diversos de seus números, os redatores do jornal apontavam a contradição entre a defesa da liberdade religiosa e a Constituição do Império, cujo

\footnotetext{
${ }^{18}$ Vale lembrar que, neste cenário, o "ordenamento jurídico imperial foi alargando os limites à liberdade religiosa", opondo a uma "minoria fiel ao Vaticano", uma elite política que, crescentemente, assumia a liberdade religiosa como mais um ícone da modernidade ocidental, apoiando e consolidando a "ideia de que o Estado brasileiro devia ampliar ao máximo as liberdades individuais no que dizia respeito à fé". (PEREIRA, 2008, p. 109).
} 
Art. $5^{\circ}$. preservava a condição oficial da religião católica apostólica romana, franqueando às demais religiões apenas a liberdade de culto doméstico ou particular, não sendo concedida ao protestantismo nenhuma vantagem em relação a qualquer outro credo diferente do católico.

Neste sentido, a liberdade de culto e o proselitismo que os protestantes faziam junto à sociedade brasileira - referida pelo jornal como "propaganda escandalosa e perigosa" - apareciam como um crime contra a Igreja e contra o Estado, justificando a crítica à tolerância religiosa para além dos limites estipulados pela Constituição de 1824, nos seguintes termos:

A tolerância religiosa entre nós não vai, nem pode ir até a propaganda, como parecem entendê-la o governo e os seus prepostos. Em uma nação como o Brasil, onde os cidadãos estão de posse da verdade religiosa, é um crime consentir que se ensine o erro: que se dê à tolerância religiosa a extensão que lhe concedem. E tanto mais criminoso é este proceder, quanto para os católicos se lhes tolhe até a liberdade de resistir com a lei a essas repetidas tentativas de especuladores, que de tudo se utilizam para seus fins criminosos. (O Apóstolo, n. 9, 27/02/1870).

Dessa forma, nota-se que, na defesa do jornal, a "liberdade da Igreja" aparecia associada à defesa da sua autonomia institucional em relação ao Estado, não se confundindo, portanto, com "liberdade religiosa", a qual significava franquear o culto público às outras denominações cristãs, concorrentes do catolicismo. Em função disso, mesmo após a separação institucional entre a Igreja católica e Estado nacional e a criação das condições jurídicas para a liberdade e o pluralismo religioso no Brasil - consagradas pela Constituição de 1891 - o catolicismo permaneceu como "modelo e referência" para o que era definido como religião, modelando o próprio direito à liberdade religiosa, "definida mais em termos de autorregularão do que de controle estatal”. (MONTERO, 2012, p. 170-71)

\section{Construindo a identidade}

Chegados a este ponto, cabe salientar os aspectos que definiam positivamente a identidade ultramontana, nas páginas do jornal O Apóstolo. Neste sentido, não restam dúvidas sobre sua postura ideológica e sobre a causa a qual se 
dispunha. Conforme registrado na edição inaugural, tratava-se de um jornal “dedicado aos interesses do Catolicismo”. (O Apóstolo, n. 1, 7/01/1866).

Este o referencial coesivo mais geral, em torno do qual buscou agregar os atores encarregados da verdadeira missão à qual se propunha e nomear os destinatários das mensagens por ele emitidas. Professava, assim, uma Igreja institucional "visceralmente ligada à Sé Romana", tomada como o novo "centro" supostamente capaz de "proteger os membros da comunidade clerical" e associado à "função e as prerrogativas do Sumo Pontífice" (SANTIROCCHI, 2015). No artigo "A Infalibilidade do Sumo Pontífice”, explicava no que consistia este dogma:

O que é pois a infalibilidade do Papa? É uma verdade certa apoiada na revelação, ou contida na palavra de Deus escrita e tradicional, pela qual cremos que Ele não pode errar quando ensina ou define Ex cathedra, ainda só e sem os Bispos matéria de fé ou de moral (...). Além de que não se deve confundir a infalibilidade com a impecabilidade, pois o Papa só é infalível nos pontos de fé e moral cristã, isto é, quando define, proclama ou ensina o que os fiéis devem crer, e o que devem ou podem obrar para conseguir a salvação eterna, estando em tudo o mais sujeito a erros e misérias da natureza humana. (O Apóstolo, n. 21, 22/05/1870).

Aos que contestavam seu estatuto de legítimo dogma, o artigo acrescentava ter ele "as notas características do dogma pelos manifestos testemunhos da Sagrada Escritura e pela universal e constante tradição da Igreja, e definição dos próprios Concílios Gerais" (O Apóstolo, n. 21, 22/05/1870). A partir deste referencial, foram designados os sentidos de pertença e alteridade ao ultramontanismo, conforme registrado na sua edição de 3 de abril de 1870:

A Infalibilidade! Eis o pesadelo do protestante e do racionalista, do liberalista e do regalista, do judeu e do cismático, do galicano e do católico liberal” e até - quem diria! - do ímpio e do ateu!!! Todos têm medo da infalibilidade do Papa, como o desertor tem medo da farda”. (O Apóstolo, n. 14, 3/4/1870).

A implementação das diretrizes da Santa Sé no Brasil, com a plena adesão ao dogma da infalibilidade papal, dependia, por sua vez, da uniformidade do pensamento ultramontano e da capacidade da Igreja moldar atitudes e comportamentos. O que, apesar de nunca ter se verificado, justifica a preocupação do jornal em estabelecer o comprometimento de toda a sociedade brasileira "com 
os sacramentos, com a reverência a Roma, a santificação dos dias de domingo, a santificação das festas e de seus atos.” (TAVARES, 2006, p. 1).

Cabia, portanto, lembrar os "Deveres dos Católicos na abertura do Concílio do Vaticano" I, louvando a "admirável união e o pleno acatamento de todo o Episcopado Católico à Santa Sé” e recomendando aos fiéis "alvoroço igual, e uma afetuosa ação de graças ao Senhor por tão assinalado benefício”, além do dever de aderir, cada vez mais, aos "sentimentos de plena submissão e confiança tranquila nas deliberações do Sacrossanto Concílio” ( $O$ Apóstolo, n. 12, 20/3/1870).

Quanto à observância dos sacramentos, recomendava, nesta mesma edição, "a grande conveniência e a suma importância do Sacramento da Confissão”; o "Sacramento do Matrimônio - chamado pelo Apóstolo o maior dos sacramentos, porque representa a união de Jesus Cristo com a sua Igreja” ( $O$ Apóstolo, n. 2,14/1/1866)19 -; versava "Sobre a educação dos filhos" - enfatizando, por exemplo, a importância da primeira comunhão (O Apóstolo, n. 43, 28/10/1866) -; os rituais fúnebres;20 a "Sepultura Eclesiástica”, 21 etc...

Outro recurso amplamente utilizado pelo jornal para criar o sentimento de coesão entre os leitores era a publicação de notícias estrangeiras, sobretudo daquelas que narravam “As notícias de Roma” ( $O$ Apóstolo, n. 50, 10/12/1871), a luta triunfante do catolicismo sobre seus inimigos no mundo e, ainda mais entusiasticamente, o acompanhamento da reunião do Concilio do Vaticano I, a partir de 1869. Neste ponto, é possível identificar estratégia semelhante a outros periódicos ultramontanos da época. Conforme análise de Di Stefano, para o caso argentino:

\footnotetext{
${ }^{19}$ Neste sentido, o jornal acusava que: “Uma das mais fortes aspirações dos inculcados preparadores do futuro do Brasil é o casamento civil". (O Apóstolo, n. 13, 1/4/1866).

${ }^{20}$ Estes, segundo passagem extraída de São Tomaz de Aquino, muito beneficiariam a Igreja pelas rezas que atraíam: "porque a Igreja Universal, instruída pela tradição dos Padres, observa que no lugar do sacrifício onde se faz mansão dos mortos, ora-se e se oferece por todos os que morreram na comunhão do corpo de Jesus Cristo". (O Apóstolo, n. 43, 28/10/1866).

${ }^{21}$ Condenava-se, neste particular, a secularização dos cemitérios, apontando-se como um de seus mais funestos efeitos o fato de que, "Secularizando os cemitérios, nunca se lembraram ou de designar um lugar para o enterramento dos cidadãos e estrangeiros que morressem fora da comunhão católica (...), ou de conservar dentro dos seus cemitérios lugar separado daquele que fosse destinado para os católicos, e que não recebesse benção". (O Apóstolo, n. 19, 8/5/1870).
} 
La difusión de las noticiais que llegaban de Roma, de Francia, de Chile o de África contribuía a generar en los lectores la conciencia - inexistente hasta entonces - de esa pertenecia a un movimento de mayor amplitud. Por cierto, la batalla contra las fuerzas de la impiedade no se había ganado ni mucho menos, y debía librársela en todos los frentes. De allí que florecieran iniciativas orientadas a combatir al mal con una de sus armas predilectas: la prensa. (DI STEFANO, 2015, p. 26).

Outro referencial positivo que aparece nas páginas do Apóstolo era aquele que enfatizava a relação entre identidade católica e identidade nacional. Neste ponto, apoiava-se não apenas no fundamento constitucional do catolicismo, como religião oficial do Império, mas no fato deste constituir a religião da maioria dos brasileiros:

Com efeito, a religião é uma coisa que pertence e se refere diretamente a cada cidadão em particular, e a todos em geral; abraça a nação inteira, exprimindo os laços que a ligam ao seu autor; logo, a religião do Estado quer dizer, religião da totalidade ou quase totalidade dos cidadãos em um país (...). De sorte que, se em sentido geral a religião é em todo o rigor da palavra católica, ou universal, no sentido particular em que neste lugar a tomamos, pode ser chamada nacional, isto é, professada por todas as pessoas que constituem a nação [...]. Para que a religião católica deixasse de ser a religião do Estado, seria mister que não fosse mais a religião da Nação; que os brasileiros perdessem sua fé: logo, enquanto a nação brasileira professar a religião católica, esta será, necessariamente, a religião do Estado". (O Apóstolo, n. 31, 4/8/1867).

Por fim, vale lembrar que, embora o ultramontanismo se opusesse a determinados aspectos da modernidade em voga, condenados como "heresias", não deixava de reivindicar sua sintonia com a evolução das sociedades e, portanto, com os próprios referenciais modernos. Afinal, é a partir da chamada geração de 1870 que novas ideias de cunho cientificista passam a invadir o Brasil, sendo incorporadas pelas elites intelectuais como os novos ícones da modernidade ocidental, chocando-se frontalmente com o tradicionalismo da Igreja Católica (ALONSO, 2002). Além disso, era preciso contrapor-se ao alinhamento circunstancial entre liberais e conservadores na defesa da imigração de origem anglo-saxônica e germânica, o que favorecia os argumentos em defesa da liberdade religiosa, como aquele defendido pelo deputado do Rio de Janeiro Luis Peixoto de Lacerda Werneck, ao reconhecer ser "indispensável atentar para as necessidades dos emigrantes (...) e dar maior latitude á que rege o exercício do culto e a pratica 
da religião, embora diversa da nossa" (WERNECK, 1865, p. 98). Na perspectiva liberal radical, aposta-se nesta solução como o "caminho de libertação do regalismo e do clericalismo", conforme formulação de Aureliano Tavares Bastos (1839-1875), registrada no seu livro A Província, de 1870, no qual associava "protestantismo" e “progresso". (BASTOS, 1975 [1870]).

Tal perspectiva chocava-se, frontalmente, com o projeto de civilização ultramontano, sob o qual estabeleceu-se o forte vínculo entre civilização e cristianismo, estendido ao binômio cristianismo e progresso. Desse modo, na oposição à vertente liberal da secularização em voga, a legitimidade política e moral do catolicismo ultramontano exigia que este estendesse o vínculo entre civilização e cristianismo, ao binômio cristianismo e progresso (SILVA, 2020). Ideais que eram qualificados com base numa conotação religiosa, que tomava o catolicismo como único e verdadeiro fundamento da sociedade moderna e secular.

Esboçava-se, desse modo, uma relação paradoxal da identidade ultramontana com as tendências em voga, segundo a qual, ao mesmo tempo negava-se o filosofismo do século - argumentando ser o catolicismo "a verdade, o protestantismo o erro, o racionalismo a impostura" ( $O$ Apóstolo, n. 29, 10/07/1870) - e reivindicava-se determinados ícones da modernidade em voga.

$\mathrm{Na}$ análise de seus argumentos, é possível identificar como o alvo principal de suas críticas aquilo que se compreendia como uma modernidade essencialmente racionalista, uma vez que a razão humana não era errada, mas "insuficiente ou impotente (...) para abranger o complexo de todos os conhecimentos". De tal forma que não se tratava de abolir a razão, mas, nas palavras do jornal, de uni-la à "revelação". (O Apóstolo, n. 21, 22/05/1870)

Nestes termos, a Igreja, "longe de se entender como instituição autoritária e retrógrada", pensava-se "como fonte da verdadeira civilização e do progresso modernos", concebendo-se como instrumento fundamental para o avanço e evolução humanos" (ROMANO, 1979). Concepção esta que levava os redatores do jornal a proclamarem: "Não somos retrógrados, nem pertencemos ao século 
passado, nem ignoramos a máxima de São Paulo", cujas palavras "querem dizer que a verdadeira ciência é incompatível com essa vã credulidade (...)”. (O Apóstolo, n. 20, 15/05/1870)

Tratava-se, portanto, de uma concepção de sociedade moderna fundada na ordem e na moral cristãs. Afinal, argumentava-se:

A Igreja não tem pátria, é cosmopolita, porque proclama a fraternidade de todos os homens. É este o alicerce da civilização moderna, o qual principiou a assentar-se na idade média, introduzindo um verdadeiro progresso, e jamais uma retroação de movimento. (O Apóstolo, n. 61, 3/6/1885).

Segundo esta concepção, o clero católico aparecia como principal agente da sociedade moderna, cujos fundamentos não podiam prescindir da religião católica, sendo o verdadeiro "elemento civilizador", um "fato essencialmente moderno", devendo "seu nascimento ao cristianismo e a sua conservação à igreja", "decorrendo da Cruz" ${ }^{22}$. O que levava os ultramontanos a se preocuparem com a instrução e moralidade deste clero, acreditando que: "Pelo adiantamento do clero de uma nação se conhece de sua civilização. A verdadeira civilização de uma nação pressupõe o desempenho da alta missão do seu clero.” (O Apóstolo, n. 28, 3/7/1870)

Tratava-se, portando, de difundir uma concepção de progresso e civilização coerentes com os ideais de ordem e os princípios do catolicismo romano. Neste sentido, longe de expressar um entrave à construção de uma sociedade moderna, tal projeto expressou uma via específica da secularização, reprisada em outros contextos latinoamericanos. Segundo Di Stefano, apesar de propugnar o catolicismo como religião oficial e a Igreja como "sociedade perfeita" - isto é, reconhecida como entidade juridicamente equivalente ao Estado -, o "modelo intransigente romano" converteu-se numa vertente da secularização, na medida em que: "La defensa de los 'derechos de la Iglesia' implica que Iglesia y Estado son dos

\footnotetext{
${ }^{22}$ Argumento este defendido em outro periódico ultramontano da época - A Cruz -, em sua crítica à obra do protestante François Guizot - Histoire générale de la civilisation en Europe depuis la chute de l'empire romain jusqu'à la Révolution française, editada em Bruxelas, em 1838 -, na qual admitia a existência de uma civilização antiga e outra moderna. (A Cruz - Jornal religioso, litterario, historico e philosophico, Rio de Janeiro, n. 43, 8 de junho de 1862, p. 2". Disponível em: https://bndigital.bn.gov.br/hemeroteca-digital. Acesso em: 3 de junho de 2018.
} 
realidades no sólo distintas, sino también necesariamente diferentes”. (DI STEFANO, 2008, p. 168)

\section{Considerações finais}

Mediante a crise do antigo modelo de relacionamento entre Igreja e Estado brasileiro - cujo marco decisivo foi a Questão Religiosa - e a acelerada expansão dos confrontantes do catolicismo - representados pelo “vendaval das liberdades modernas' que começava a açoitar o Brasil” (CIARALLO, 2011, p. 93) representantes do pensamento ultramontano mobilizaram-se num verdadeiro esforço de sobrevivência enquanto grupo religioso institucionalizado, reproduzindo no plano discursivo a própria dinâmica da secularização, entendida como a “reorganização permanente da religião” (HERVIEU-LÉGER, 2004), em contextos de modernidade. Dessa forma, instrumentos essencialmente modernos, utilizados pelos setores seculares acusados como "inimigos da Igreja”, foram apropriados pelos ultramontanos como veículos privilegiados na propagação de determinadas concepções e esquemas de pensamento, muitas vezes contrários a aspectos específicos da própria modernidade.

Dentre estes veículos, a imprensa periódica se revelou crucial, viabilizando a simultânea construção da modernidade política e religiosa, no Brasil oitocentista. O que se observa, neste sentido, é que, através da imprensa periódica católica, os representantes do ultramontanismo realocaram sua influência junto à sociedade civil, ao passo que diminuía sua participação política direta através do Estado e seus mecanismos institucionais. Assim, à medida que o Estado brasileiro separouse institucionalmente da Igreja católica, constituindo-se "como esfera política própria", observou-se "um retraimento do catolicismo para o espaço social", permanecendo influente na sociedade e modelando o que institucionalmente se convencionava chamar de "religião", cujo modelo de referência era o catolicismo. De tal forma que, contrariando as teses gerais da modernidade e da secularização, o compromisso normativo resultante do movimento de produção de novas institucionalidades religiosas - no âmbito do qual se construiu o Estado laico no 
Brasil - não teve como "decorrência necessária e mecânica a privatização da religião na esfera doméstica" (MONTERO, 2006, p. 49-50) e, tampouco, a secularização da sociedade. (ORO, 2011, p. 235)

Esta a dinâmica que se procurou identificar nas páginas do jornal $O$ Apóstolo, a partir da qual ultramontanos laicos e clérigos buscaram forjar a identidade ultramontana no Brasil da segunda metade do século XIX. Em seus diversos números, registram-se aqueles parâmetros a partir dos quais os processos identitários podem ser pensados e analisados (ENNES; MARCON, 2014, p. 277): a definição dos atores sociais de algum modo articulados ao grupo; a explicitação dos motivos das disputas de pertencimento, dos elementos morais e normativos reguladores do meio pelos quais estes atores entraram em interação, assim como dos contextos históricos e sociais nos quais foram produzidos; além da produção de uma memória capaz de remeter a uma trajetória singular da Igreja católica no Brasil, apresentada como fundamento coesivo da própria nacionalidade.

Por fim, uma vez que a identidade ultramontana deveria englobar sacerdotes e fiéis, o jornal buscou criar um habitus nos leitores (BOURDIEU, 1974), de modo a direcionar determinados tipos de ações ou comportamentos, fundamentando sua causa em três pontos essenciais: a defesa de uma moral específica; a legitimação do catolicismo sobre o protestantismo e a crítica a determinados aspectos da modernidade.

Apesar da atuação a partir destes parâmetros, com base nos quais buscaram criar uma coesão em torno da Igreja romana e modelar as mentes e as almas dos brasileiros (SANTIROCCHI, 2015), são raros os momentos em que o jornal se esforçou por definir positivamente o ultramontanismo. Em geral, tal definição era tecida pela oposição aos seus vários sentidos de alteridade, como fica expresso no trecho abaixo:

E o que é este tão decantado ultramontanismo? No meio da confusão de ideias que se tem formado desta palavra, parece-me que o sentido dela ficaria mais claramente fixado e defino confrontando-o com as teorias do sistema contrário, que tudo sujeita à supremacia do poder temporal, e que há sido 
designado de febronismo (sic), josefismo, regalismo e galinanismo (sic), que como é sabido são eternos inimigos desse inculcado ultramontanismo. (...) Sabeis quais são esses ultramontanos, exclamava um sábio e venerado prelado francês destes últimos tempos? Ah o chefe da Igreja universal rodeado de todas as Igrejas particulares, exceto a galicana! Pois que as suas máximas e o que ela chama suas liberdades, a distinguem de todas as outras (...). Assim que pode-se dizer que a maioria das Igrejas dos Estados Católicos da Europa é ultramontana na legítima acepção desta palavra, isto é, reconhece e tributa a devida homenagem à independência e liberdade da Igreja de Deus (...). Eis, Augusto e Digníssimos Senhores, o ultramontanismo que professa o clero Católico, e que a cada passo se nos lança em rosto, como uma injúria! (O Apóstolo, n. 18, 3/07/1866).

\section{REFERÊNCIAS}

A CRUZ: Jornal religioso, litterario, historico e philosophico, Rio de Janeiro, 1861-1864. Disponível em: https://bndigital.bn.gov.br/hemeroteca-digital. Acesso em: 3 jun. 2018.

ABREU, M. O Império do divino. Festas religiosas e cultura popular no Rio de Janeiro, 1830-1900. 2. ed. Rio de Janeiro: Nova Fronteira: 1999.

ALONSO, A. Ideias em movimento - A geração 1870 na crise do Brasil Império. Rio de Janeiro: Paz e Terra, 2002.

ANDERSON, B. Nação e consciência nacional. São Paulo: Ática, 1989.

ARAÚJO, A. C. As ciências sagradas na cidadela da razão. In: A. C. ARAÚJO (coord.). O Marquês de Pombal e a Universidade. 2. ed. Coimbra: Imprensa da Universidade de Coimbra, 2014. p. 77-106.

ASAD, T. Formations of the Secular: christianity, islam, modernity. California: Stanford, 2003, $280 \mathrm{p}$.

BASTOS, A. C. T. A Província: estudo sobre a descentralização no Brasil. 3. ed. São Paulo: Ed. Nacional, 1975 [1870].

BOURDIEU, P. A economia das trocas simbólicas. São Paulo, Perspectiva, $7^{\mathrm{a}}$. Ed., 2013, 424 p.

CASANOVA, J. Rethinking Secularization: A Global Comparative Perspective”. The Hedgehog Review, v. 8, n. 1-2, p. 7-22, 2006.

CIARALLO, G. O tema da liberdade religiosa na política brasileira do século XIX: uma via para a compreensão da secularização da esfera política. Revista de Sociologia Política, v. 19, n. 38, 2011, p. 85-99. 
DI STEFANO, R. ¿De qué hablamos cuando decimos 'Iglesia'? Reflexiones sobre el uso historiográfico de un término polisémico”. Ariadna Histórica. Lenguajes, conceptos, metáforas, v.1, n.1, 2012, p. 197-222.

DI STEFANO, R. Disidencia Religiosa y Secularización en el Siglo XIX iberoamwericano: cuestiones conceptuales y metodológicas. Projeto História, São Paulo, n. 37, 2008, p. 157-178.

DI STEFANO, R. La Revista La Relijion (1853-1862) y La formación de um círculo intelectual ultramontano em Buenos Aires. In: C. RODRIGUES, et. alli. Manifestações do Pensamento Católico na América do Sul. São Paulo: Fonte Editorial, 2015, p. 1542.

DI STEFANO, R. Modernidad Religiosa y Secularización em La Argentina Del siglo XIX. In: E. M. de A. MARANHÃO FILHO (org.). Política, religião e diversidades: educação e espaço público. Florianópolis: ABHR /Fogo, 2018, p. 133-147. Disponível em: http://abhr2018.paginas.ufsc.br/files/2018/10/Miolo_ABHR_Vol3-rev-1.pdf. Acesso em 07/01/19.

DI STEFANO, R. Por una historia de la secularización y de la laicidad en la Argentina. Quinto Sol. vol. 15, n. 1, 2011, p. 1-32

EISENSTADT, S. N. Multiple Modernities. Daedalus, vol. 129, n. 1, 2000, p. 1-29

ENNES, M. A.; MARCON, F. 2014. Das identidades aos processos identitários: repensando conexões entre cultura e poder. Sociologias, ano 16, n. 35, p. 274-305.

GUERRA, F. X.. Modernidad e independencias: ensayos sobre las revoluciones hispânicas: Encuentro, 2009. 407 p.

HADDEN, J. K. Toward Desacralizing Secularization Theory. Social Forces, vol. 65, n. 3, 1987, p. 587-611.

HAUCK, J. F. História da Igreja no Brasil: ensaio de interpretação a partir do povo: segunda época: a Igreja no Brasil no século XIX. São Paulo, Paulinas; Petrópolis: Vozes, 1992, 688 p.

HAUPT, H.G. Religião e nação na Europa no século XIX: algumas notas comparativas. Estudos Avançados, vol. 22, n. 62, 2008, p. 77-94. Disponível em: <http://www.scielo.br>. Acesso em 02/02/2017.

HERVIEU-LÉGER, D. El peregrino y el convertido: La religión en movimiento. México: Ediciones del Helénico, 2004.

LUSTOSA, O. de F. Os bispos do Brasil e a imprensa. São Paulo: Loyola/CPEHIB, 1983, $199 \mathrm{p}$.

MANOEL, Ivan Aparecido. O pêndulo da história: tempo e eternidade no pensamento católico (1800-1960). Maringá: Eduem, 2004. 
MARIN, Jérri Roberto. Reflexões sobre a imprensa católica no Brasil. Religião e Sociedade, Rio de Janeiro, v. 38, n. 3, mai./ago. 2018, p. 197-217.

MONTERO, P. Controvérsias religiosas e esfera pública: repensando as religiões como discurso. Religião e Sociedade, v. 32, n. 1, 2012, p. 167-183.

MONTERO, P. Religião, pluralismo e esfera pública no Brasil. Novos EstudosCEBRAP, n. 74, 2006, p. 47-65.

MONTERO, P. Secularização e espaço público: a reinvenção do pluralismo religioso no Brasil. Etnográfica, v. 13, n. 1, 2009, p. 7-16.

NEVES, F. R. A voz e a pena a serviço da Igreja. A imprensa católica e a ampliação da esfera pública no Rio de Janeiro no final do século XIX. In: Anais do 9o Encontro Nacional de História da Mídia - GT de História da Mídia, 2013. Disponível em: http://www.ufrgs.br/alcar/encontros-nacionais-1/encontros-nacionais/9o-encontro2013/artigos/gt-historia-do-jornalismo.

O APÓSTOLO: periódico religioso, moral e doutrinário, consagrado aos interesses da religião e da sociedade. Rio de Janeiro, 1866-1901. Disponível em:

http://memoria.bn.br/hdb/periodico.aspx. Acesso em: 13 maio 2017.

ORO, A. P. A laicidade no Brasil e no Oriente: algumas considerações. Civitas: Revista de ciências sociais. Vol. 11, n. 2, 2011, p. 221-237

PEREIRA, R. da N. M. A salvação do Brasil: as missões protestantes e o debate políticoreligioso do século XIX. Rio de Janeiro, RJ. (Tese de Doutorado em História Política). UERJ, 2008, 436 p.

PINHEIRO, A. O Apóstolo, ano I: a autocompreensão de um jornal católico do século XIX. In: Anais do XIV Congresso de Ciências da Comunicação na Região Sudeste Intercom, Divisão Temática de Jornalismo, Rio de Janeiro, 2009. Disponível em: http://www.intercom.org.br/pesquisa/pesquisa.shtml. Acesso em 13 maio 2017.

RAMIRO JR., Luis Carlos. O conceito de civilização e o discurso ultramontano no Brasil. Ariadna histórica. Lenguajes, conceptos, metáforas, n. 5 (2016), p. 69-107.

RANQUETAT JR., C. A. Laicidade à Brasileira: estudo sobre a controvérsia em torno da presença de símbolos religiosos em espaços públicos. Jundiaí: Paco Editorial, 2016, 344 p.

RODRIGUES, A. M. M. (pref.). A Igreja na República. Brasília, UNB. Coleção pensamento político republicano. vol. 4, 1981.

SANTIROCCHI, I. D. Questão de Consciência: os Ultramontanos no Brasil e o Regalismo do Segundo Reinado (1840-1889). Belo Horizonte: Fino Traço, 2015, 520 p.

SANTIROCCHI, I. D. Uma questão de revisão de conceitos: Romanização Ultramontanismo - Reforma". Temporalidades - Revista Discente do Programa de Pósgraduação em História da UFMG, vol. 2, n. ${ }^{\circ}$ 2, 2010, p. 24-33. 
SANTIROCCHI, Ítalo D. O paradigma tridentino e a Igreja Católica no Brasil oitocentista: modernidade e secularização, in: Reflexão, v. 42, n. 2, p. 169-181, 2017.

SILVA, A. R. C. da. As experiências da Modernidade e da Secularização no discurso ultramontano da segunda metade do século XIX: uma discussão a partir da História dos Conceitos. In: ANAIS do VI Congresso da Associação Nacional de PósGraduação e Pesquisa em Teologia e Ciências da Religião: Religião, Migração e Mobilidade Humana (ANPTECRE). Pontifícia Universidade Católica de Goiás, Goiânia, 2017, p. 101-109.

SILVA, A. R. C. da; CARVALHO, T. da R. Ultramontanismo e Protestantismo no período regencial: uma análise da crítica panfletária dos padres Pereca e Tilbury missão metodista no Brasil. Almanack, n. 15, 2017, p. 143-182.

SILVA, A. R. C. da; DI STEFANO, R. (orgs.). História das religiões em perspectiva: desafios conceituais, diálogos interdisciplinares e questões metodológicas. Curitiba: Editora Primas, 2018, 389 p.

SILVA, A. R. C. da; LOURENÇO, L. da S.. Entre a política e a religião: uma análise da imprensa periódica feijoísta, na conjuntura de 1834 a 1835, in: Revista Brasileira de História das Religiões, v. 7, n. 21, 2015, p. 207-229.

SILVA, A. R. C., da; MARTINEZ, I. ; STEFANO, R.; MONREAL, S. RELIGIÓN Y CIVILIZACIÓN EN ARGENTINA, BRASIL Y URUGUAY (1750-1899). Ariadna histórica. Lenguajes, conceptos, metáforas, v. 9, 2020, p. 17-52.

SOUZA, Françoise Jean de Oliveira. Do Altar à Tribuna. Os Padres Políticos na Formação do Estado Nacional Brasileiro (1823-1841). Rio de Janeiro, RJ. (Tese de doutoramento em História), UERJ, Instituto de Filosofia e Ciências Humanas, 2010.

TAVARES, M. D. Progresso e civilização à luz ultramontana: jornais católicos no Sul do Brasil - Porto Alegre, Século XIX. Revista Histórica. São Paulo: Arquivo do Estado de São Paulo, n. 12, 2006, p. 1-7. Disponível em:

http://www.arquivoestado.sp.gov.br/site/assets/publicacao/anexo/historica12.pdf. Acesso em: 11 fev. 2020.

WERNECK, Luís Peixoto de Lacerda. Ideias sobre colonização precedidas de uma sucinta exposição dos principios gerais que regem a população, Rio de Janeiro, Laemmert, 1865. Disponível em: https://digital.bbm.usp.br/handle/bbm/7619. Acesso em: 11 fev. 2020. 